Doi: HTTPS://DOI.ORG/10.23910/IJBSM/2017.8.5.1785

\title{
Effect of Seed Coating with Polymer, Fungicide and Insecticide on Seed Quality in Sorghum (Sorghum bicolor (L.) Moench) during Storage
}

\author{
P. S. Rao*, M. Sudha Rani, R. Ankaiah, M. Rajasri and K. V. S. Meena Kumari
}

Seed Research and Technology Centre, Rajendranagar, Hyderabad, Andhra Pradesh (500 030), India

\section{Corresponding Author}

P. S. Rao

e-mail: sampalrao@gmail.com

\author{
Article History \\ Article ID: AR1785 \\ Received in $18^{\text {th }}$ January, 2017 \\ Received in revised form $15^{\text {th }}$ August, 2017 \\ Accepted in final form $27^{\text {th }}$ September, 2017
}

\begin{abstract}
The present study was undertaken with sorghum hybrid CSH 9 during 2009-10 and 2010-11 through seed coating with polymers in combination with pesticide and fungicide. The objective was to standardize the seed coating protocol for enhancement of seed quality

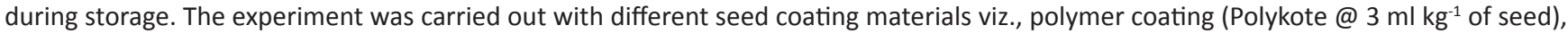
polymer coating+thiram 75\% wp @ $2.5 \mathrm{~g} \mathrm{~kg}^{-1}$ of seed, polymer coating+imidacloprid @ $4 \mathrm{ml} \mathrm{kg}^{-1} \mathrm{seed}$, polymer coating+thiram 75\% wp @ $2.5 \mathrm{~g} \mathrm{~kg}^{-1}$ of seed+imidacloprid @ 4 ml kg-1 seed and vitavax 200 @ $2 \mathrm{~g} \mathrm{~kg}^{-1}$ seed along with untreated seed. The seed material was stored in both cloth bags and 700 guage polythene bags and data was recorded on various quality parameters during storage. The results revealed that irrespective of the storage container, significantly superior germination percent (76 and 75), seedling vigour index (2895 and 2205 ) and field emergence ( 81 and $79 \%$ ) was recorded with polymer coating+thiram+imidacloprid over untreated control at ten months of storage during 2009 and 10 when stored in polythene bag. There was no incidence of pathogen in the seed lots of all the treatments initially, which rose up to $4.5 \%$ in control. However, a lower per cent of infection of $0-2.5$ was maintained in the seed lots stored in 700 gauge polythene bags coated with polymer coating+thiram+imidacloprid at ten months of storage. Thus, the sorghum seed treated with polymer coating+thiram+imidacloprid before storage can maintain the seed quality up to ten months of storage.
\end{abstract}

Keywords: Seed coating, synthetic polymer, sorghum, seed storage

\section{Introduction}

Sorghum popularly known as Jowar is the fifth most important cereal crop in the world after wheat, rice, maize and barley. It is found in the arid and semi arid parts of the world, due to its feature of being extremely drought tolerant. The nutritional value of sorghum is same as that of corn and that is why it is gaining importance as livestock feed. Sorghum is also used for ethanol production, starch production, production of adhesives and paper other than being used as food and fodder. Out of the total area under sorghum cultivation in India, $50 \%$ is cultivated in Maharashtra. Similarly, out of the total production of sorghum in the nation, $52 \%$ is from Maharashtra, Karnataka, Andhra Pradesh and Tamil Nadu (India). One more advantage of this crop is that it can be grown in both kharif and rabi seasons. Also, it can handle and grow on a wide range of soil types starting from fertile to less nutrient soils. It is realized that there is a wide scope to make the crop popular in dry farming areas and that this crop requires redesigning of agricultural strategy to improve the productivity of the crop by introducing new hybrid seeds and improving input facilities and seed quality during seed storage.
Modern high-tech agriculture with its modern technology demands that each and every seed material should readily germinate and produce a vigorous seedling for ensuring high marketable yield (Maiti and Pramanik, 2013). So, maintenance of seed vigour and viability during storage is a matter of concern in India. Seed coating involves application of required materials to the seed-soil interface and the method allows using minor amounts of materials to affect micro environment of each seed (Gevrek et al., 2012). Seed coating practices have recently become the most studied area with its benefits of reducing costs and increasing the efficiency of the materials (Zeng and Shi, 2008; Tiwari et al., 2011). The losses of stored grain may occur to the extent of $10-15 \%$ due to storage pests and fungal moulds development (Pradhan, 1964). The nutritive value of food, viability, vigour and the cooking quality of sorghum seed will be deteriorated due to these biotic constraints during storage. Film coating technology is a sophisticated process of applying precise amount of active ingredients along with a liquid material directly on to the seed surface without obscuring its shape and the total seed weight may increase upto 1 to $2 \%$ (Kunkur et al., 2007; Shakuntala et al., 2010). The film formulations consist of a mixture of polymer, plasticizer and colourants 
(Robbani, 1994) that are commercially available as ready to use liquids or as dry powders (Ni, 1997). Seed coating provides an opportunity to package effective quantities of materials so that they can improve the germination and seedling growth. The polymer film coating may act as physical barrier, which has been reported to reduce the leaching of inhibitors from the seed coverings and may restrict oxygen diffusion to the embryo (Vanangamudi et al., 2003). Seed coating with synthetic polymer (polykote) in combination with fungicides may be a potent tool for quality hybrid seed storage and effective disease management against seed and soil-borne pathogens (Pham Long Giang and Rame Gouda, 2007). It is a need of the day to develop polymer based seed coats that can prevent moisture entry, fungus penetration and insect attack during storage (Kumar et al., 2007). Hence, the preset study was taken up with an objective of understanding the effect of polymer coating along with insecticide and fungicide on viability, vigour and other qualitative parameters of sorghum over a period of storage.

\section{Materials and Methods}

The study was conducted at Seed Research and Technology Centre, Rajendranagar, ANGRAU, Hyderabad (India) during 2009-10 and 2010-11. Freshly harvested produce of sorghum hybrid $\mathrm{CSH}-9$ was collected and cleaned, dried and treatments viz., Polymer coating @ $3 \mathrm{ml} \mathrm{kg}^{-1}$ seed $\left(\mathrm{T}_{1}\right)$; Polymer coating+Thiram (75\%wp @ $\left.2.5 \mathrm{~g} \mathrm{~kg}^{-1}\right)\left(\mathrm{T}_{2}\right)$, Polymer coating+Imidacloprid (@ $4 \mathrm{ml} \mathrm{kg}^{-1}$ ) $\left(\mathrm{T}_{3}\right)$, polymer coating+thiram+imidacloprid $\left(\mathrm{T}_{4}\right)$ and vitavax $200 @ 2 \mathrm{~g} \mathrm{~kg}^{-1}$ seed $\left(T_{5}\right)$ along with untreated control (To) were imposed. The treated and un-treated seed packed in cloth and polythene bags (700 Gauge) were stored under ambient storage conditions in the laboratory. Data were collected on various seed quality parameters during storage at bimonthly intervals.
The analysis was carried out using Factorial CRD. The statistical analysis was done as per procedure described by Panse and Sukhatme (1985).

\section{Results and Discussion}

\subsection{Effect of polymer coating on germination of seed}

The germination per cent was gradually decreased with increase of storage period. After 10 months of storage it was observed that the seed coating with polymer+imidacloprid and Polymer coating+Thiram+Imidacloprid were found to be superior with highest percent of germination (76) when stored in polythene bag during 2009-10 (Table 1). The decline in the germination per cent might be attributed to ageing effect, leading to depletion of food reserves and decline in synthetic activity of embryo apart from death of seed because of fungal invasion, insect damage and storage conditions (Kunkur et al., 2007 ). Thiram act as a protective agent seed deterioration due to fungal invasion and physiological ageing as a result of which seed viability was maintained for a comparatively longer period of time (Savitri et al., 1994). The film formed around the seed coat acts as a physical barrier. The higher germination of seed coated with polymer is due to increase in rate of imbibition. There was no significant difference between the containers used. Both cloth bag and polythene bag performance with respect to germination per cent was on par with each other. When the experiment was repeated during 2010-11 also the treatment similar results were realized (Table 2). The same treatment Polymer coating+Thiram+Imidacloprid recorded significantly superior performance with respect to germination (75\%) was recorded over other treatments besides control. These findings are in agreement with the results of Veraja and Rai (2015) in blackgram and Rattinassababady et al. (2012).

Table 1: Influence of seed coating with polymer, fungicide and insecticide on Germination (\%) of sorghum seeds during storage (2009-10)

\begin{tabular}{|c|c|c|c|c|c|c|c|c|c|c|c|c|c|}
\hline \multirow{3}{*}{$\begin{array}{l}\text { Treatment }(\mathrm{T}) \\
\text { Container }(\mathrm{C}) \\
\end{array}$} & \multicolumn{12}{|c|}{ Duration (Months after storage) } & \multirow{3}{*}{ Mean } \\
\hline & \multicolumn{2}{|c|}{ Initial } & \multicolumn{2}{|c|}{2} & \multicolumn{2}{|c|}{4} & \multicolumn{2}{|c|}{6} & \multicolumn{2}{|c|}{8} & \multicolumn{2}{|c|}{10} & \\
\hline & $\mathrm{C}_{1}$ & $\mathrm{C}_{2}$ & $\mathrm{C}_{1}$ & $\mathrm{C}_{2}$ & $\mathrm{C}_{1}$ & $\mathrm{C}_{2}$ & $\mathrm{C}_{1}$ & $\mathrm{C}_{2}$ & $\mathrm{C}_{1}$ & $\mathrm{C}_{2}$ & $\mathrm{C}_{1}$ & $\mathrm{C}_{2}$ & \\
\hline $\mathrm{T}_{0}$ & 86 & 88 & 91 & 93 & 80 & 82 & 74 & 78 & 70 & 74 & 62 & 66 & 79 \\
\hline $\mathrm{T}_{1}$ & 88 & 89 & 90 & 91 & 81 & 83 & 79 & 80 & 72 & 75 & 66 & 70 & 80 \\
\hline$T_{2}$ & 89 & 90 & 92 & 95 & 86 & 90 & 82 & 85 & 76 & 81 & 70 & 74 & 84 \\
\hline $\mathrm{T}_{3}$ & 89 & 90 & 89 & 91 & 84 & 86 & 79 & 85 & 77 & 80 & 73 & 76 & 83 \\
\hline $\mathrm{T}_{4}$ & 88 & 89 & 92 & 90 & 87 & 90 & 79 & 84 & 78 & 82 & 75 & 76 & 84 \\
\hline $\mathrm{T}_{5}$ & 88 & 89 & 79 & 92 & 80 & 87 & 78 & 80 & 74 & 76 & 67 & 71 & 80 \\
\hline \multirow[t]{2}{*}{ Mean } & 88 & 89 & 89 & 92 & 83 & 86 & 78 & 82 & 74 & 78 & 68 & 72 & \\
\hline & C & & $\mathrm{T}$ & & D & & $\mathrm{C} \times \mathrm{T}$ & & $C \times D$ & & $T \times D$ & & $C \times T \times D$ \\
\hline $\mathrm{CD}(p=0.05)$ & 0.31 & & 0.54 & & 0.54 & & 0.76 & & 0.76 & & 1.35 & & 1.88 \\
\hline
\end{tabular}

$\mathrm{C}_{1}$ : Cloth bag; $\mathrm{C}_{2}$ : Polythene bag (700 gauges); Duration (D): Months after storage; $\mathrm{T}_{0}$ : Untreated (Control); $\mathrm{T}_{1}:$ Polymer coating (Polykote @ $3 \mathrm{ml} \mathrm{kg}{ }^{-1}$ seed); $\mathrm{T}_{2}$ : Polymer coating+Thiram (75\% wp @ $2.5 \mathrm{~g} \mathrm{~kg}^{-1}$ ); $\mathrm{T}_{3}$ : Polymer coating+imidacloprid (@ $4 \mathrm{ml}$ $\left.\mathrm{kg}^{-1}\right) ; \mathrm{T}_{4}$ : Polymer coating+thiram+imidacloprid; $\mathrm{T}_{5}$ : Vitavax $200 @ 2 \mathrm{~g} \mathrm{~kg}^{-1}$ seed 
Table 2: Influence of seed coating with polymer, fungicide and insecticide on Germination (\%) of sorghum seeds during storage (2010-11)

\begin{tabular}{|c|c|c|c|c|c|c|c|c|c|c|c|c|c|}
\hline \multirow{2}{*}{$\begin{array}{l}\text { Treatment }(\mathrm{T}) \\
\text { Container }(\mathrm{C})\end{array}$} & \multicolumn{2}{|c|}{ Initial } & \multicolumn{2}{|c|}{$2 \mathrm{MAS}$} & \multicolumn{2}{|c|}{$4 \mathrm{MAS}$} & \multicolumn{2}{|c|}{6 MAS } & \multicolumn{2}{|c|}{$8 \mathrm{MAS}$} & \multicolumn{2}{|c|}{10 MAS } & \multirow[t]{2}{*}{ Mean } \\
\hline & $C_{1}$ & $\mathrm{C}_{2}$ & $\mathrm{C}_{1}$ & $\mathrm{C}_{2}$ & $C_{1}$ & $\mathrm{C}_{2}$ & $\mathrm{C}_{1}$ & $\mathrm{C}_{2}$ & $\mathrm{C}_{1}$ & $\mathrm{C}_{2}$ & $\mathrm{C}_{1}$ & $\mathrm{C}_{2}$ & \\
\hline$T_{0}$ & 86 & 88 & 85 & 87 & 82 & 84 & 74 & 72 & 69 & 70 & 61 & 65 & 77 \\
\hline $\mathrm{T}_{1}$ & 88 & 89 & 88 & 83 & 81 & 83 & 78 & 79 & 71 & 75 & 68 & 70 & 79 \\
\hline$T_{2}$ & 89 & 91 & 86 & 90 & 82 & 84 & 73 & 78 & 70 & 74 & 58 & 60 & 78 \\
\hline $\mathrm{T}_{3}$ & 89 & 90 & 87 & 89 & 81 & 80 & 74 & 72 & 71 & 67 & 69 & 65 & 78 \\
\hline $\mathrm{T}_{4}$ & 88 & 89 & 90 & 93 & 84 & 89 & 80 & 85 & 74 & 77 & 70 & 75 & 83 \\
\hline $\mathrm{T}_{5}$ & 88 & 89 & 84 & 86 & 78 & 83 & 72 & 78 & 70 & 75 & 65 & 70 & 78 \\
\hline \multirow[t]{2}{*}{ Mean } & 88 & 89 & 86 & 88 & 81 & 84 & 75 & 77 & 70 & 72 & 65 & 67 & \\
\hline & C & & $\mathrm{T}$ & & D & & $\mathrm{C} \times \mathrm{T}$ & & $C \times D$ & & $T \times D$ & & $C \times T \times D$ \\
\hline $\mathrm{CD}(p=0.05)$ & 0.35 & & 0.60 & & 0.60 & & 0.85 & & 0.85 & & 1.48 & & 2.09 \\
\hline
\end{tabular}

\subsection{Effect of polymer coating on seedling vigour index (SVI)}

Similarly, After 10 months of storage the highest seed vigour index of 2895 and 2205 was recorded with treatment polymer coating+thiram+imidacloprid during 2010 and 2009 respectively which is significantly superior over control when the seed was stored in polythene bag. The sorghum seed stored in polythene bag was proved to be superior over cloth bag with respect to seedling vigour of 2604 and 1987 during 2009 and 2010 (Table 3 and 4), respectively. The higher SVI in polymer coating along with fungicide and insecticides might be due to more germination, root and shoot length and seedling dry weight. These findings are in line with Verma and Verma (2014) in sorghum, Almeida et al. (2014) in rice Kaushik et al. (2014) in maize and Gomathi et al. (2014) in blackgram. The polymer coating and chemical treatments keep the seed intact, as it acts as binding material; it covers the minor cracks and aberration as the seed coat thus blocking the fungal invasion. It may also act as a physical barrier, which reduces leaching of inhibitors from seed covering and restricts oxygen movement and thus reducing the respiration of embryo thereby reducing the ageing effect on seeds (Vanangamudi et al., 2003). Further, the synergetic effect of both polymers and chemicals might have contributed for better germination and vigour and slow down the process of deterioration as compared to control.

\subsection{Effect of polymer coating on field emergence}

Superior performance was also noticed for field emergence in sorghum seed coated with Polymer coating+ Thiram+Imidacloprid and stored in polythene bag. Mean field emergence to a tune of $81 \%$ was noticed in this treatment. However, untreated control seed lot recorded only $69 \%$ of field emergence during 2010 . The superiority was also seen during 2009 , where $79 \%$ of field emergence recorded in the treated lot $\left(\mathrm{T}_{4}\right)$. The higher field emergence of seed coated with polymer was due to increased rate of imbibitions, where the fine particles of coating act as moisture attracting material. However, control showed $69 \%$ of field emergence (Table 5 and 6). Similar results were also reported by Pham

Table 3: Influence of seed coating with polymer, fungicide and insecticide on vigour index of sorghum seeds during storage (2009-10)

\begin{tabular}{|c|c|c|c|c|c|c|c|c|c|c|c|c|c|}
\hline \multirow{3}{*}{$\begin{array}{l}\text { Treatment }(\mathrm{T}) \\
\text { Container }(\mathrm{C}) \\
\end{array}$} & \multicolumn{12}{|c|}{ Duration (Months after storage) } & \multirow{3}{*}{ Mean } \\
\hline & \multicolumn{2}{|c|}{ Initial } & \multicolumn{2}{|c|}{2} & \multicolumn{2}{|c|}{4} & \multicolumn{2}{|c|}{6} & \multicolumn{2}{|c|}{8} & \multicolumn{2}{|c|}{10} & \\
\hline & $\mathrm{C}_{1}$ & $\mathrm{C}_{2}$ & $\mathrm{C}_{1}$ & $\mathrm{C}_{2}$ & $\mathrm{C}_{1}$ & $\mathrm{C}_{2}$ & $\mathrm{C}_{1}$ & $\mathrm{C}_{2}$ & $\mathrm{C}_{1}$ & $\mathrm{C}_{2}$ & $\mathrm{C}_{1}$ & $\mathrm{C}_{2}$ & \\
\hline$T_{0}$ & 2552 & 2564 & 2416 & 2897 & 2492 & 2622 & 2454 & 2418 & 1805 & 2132 & 1174 & 1735 & 2271 \\
\hline $\mathrm{T}_{1}$ & 2894 & 3771 & 2776 & 3207 & 2400 & 2320 & 2380 & 2765 & 1986 & 2290 & 1896 & 1922 & 2550 \\
\hline $\mathrm{T}_{2}$ & 2525 & 3712 & 2721 & 3395 & 2217 & 2953 & 2163 & 2724 & 2120 & 2485 & 1920 & 2215 & 2595 \\
\hline$T_{3}$ & 1694 & 2795 & 2411 & 2685 & 2010 & 2215 & 2065 & 2173 & 1965 & 2169 & 1695 & 1964 & 2153 \\
\hline $\mathrm{T}_{4}$ & 2920 & 2959 & 2685 & 2903 & 2290 & 2840 & 2286 & 2836 & 2037 & 2705 & 1987 & 2205 & 2526 \\
\hline $\mathrm{T}_{5}$ & 2009 & 2009 & 2903 & 2112 & 1601 & 2064 & 1562 & 1905 & 1455 & 1809 & 1105 & 1603 & 1741 \\
\hline \multirow[t]{2}{*}{ Mean } & 2432 & 2968 & 2390 & 2866 & 2168 & 2502 & 2151 & 2469 & 1894 & 2265 & 1629 & 1940 & \\
\hline & C & & $\mathrm{T}$ & & D & & $\mathrm{C} \times \mathrm{T}$ & & $C \times D$ & & $T \times D$ & & $C \times T \times D$ \\
\hline $\mathrm{CD}(p=0.05)$ & 3.36 & & 5.82 & & 5.82 & & 8.23 & & 8.23 & & 14.25 & & 20.15 \\
\hline
\end{tabular}




\begin{tabular}{|c|c|c|c|c|c|c|c|c|c|c|c|c|c|}
\hline \multirow[t]{2}{*}{ Treatment $(\mathrm{T})$} & \multicolumn{12}{|c|}{ Duration (Months after storage) } & \multirow{3}{*}{ Mean } \\
\hline & \multicolumn{2}{|c|}{ Initial } & \multicolumn{2}{|c|}{2} & \multicolumn{2}{|c|}{4} & \multicolumn{2}{|c|}{6} & \multicolumn{2}{|c|}{8} & \multicolumn{2}{|c|}{10} & \\
\hline Container (C) & $\mathrm{C}_{1}$ & $\mathrm{C}_{2}$ & $\mathrm{C}_{1}$ & $\mathrm{C}_{2}$ & $\mathrm{C}_{1}$ & $\mathrm{C}_{2}$ & $\mathrm{C}_{1}$ & $\mathrm{C}_{2}$ & $\mathrm{C}_{1}$ & $\mathrm{C}_{2}$ & $\mathrm{C}_{1}$ & $\mathrm{C}_{2}$ & \\
\hline$T_{0}$ & 2945 & 2832 & 2632 & 2749 & 2509 & 2432 & 2497 & 2334 & 2205 & 2125 & 1959 & 2014 & 2436 \\
\hline $\mathrm{T}_{1}$ & 2861 & 3428 & 2424 & 3572 & 2386 & 3221 & 2308 & 3187 & 2251 & 2734 & 1985 & 2336 & 2724 \\
\hline $\mathrm{T}_{2}$ & 2592 & 2636 & 2363 & 2376 & 2245 & 2234 & 2120 & 2187 & 1986 & 1854 & 1854 & 1756 & 2183 \\
\hline $\mathrm{T}_{3}$ & 2564 & 2756 & 2456 & 2572 & 2325 & 2364 & 2154 & 2031 & 1965 & 2014 & 1554 & 1959 & 2226 \\
\hline$T_{4}$ & 3051 & 3203 & 3185 & 3570 & 2935 & 3315 & 2930 & 3004 & 2709 & 2914 & 2604 & 2895 & 3026 \\
\hline$T_{5}$ & 2954 & 3016 & 2735 & 2861 & 2532 & 2741 & 2233 & 2630 & 1924 & 2241 & 1654 & 1965 & 2457 \\
\hline \multirow[t]{2}{*}{ Mean } & 2828 & 2632 & 2489 & 2374 & 2173 & 1935 & 2978 & 2950 & 2718 & 2562 & 2314 & 2154 & \\
\hline & C & & $\mathrm{T}$ & & D & & $\mathrm{C} \times \mathrm{T}$ & & $C \times D$ & & $T \times D$ & & $C \times T \times D$ \\
\hline $\mathrm{CD}(p=0.05)$ & 1.61 & & 2.80 & & 2.80 & & 3.96 & & 3.96 & & 6.85 & 9.69 & 20.15 \\
\hline
\end{tabular}

Table 5: Influence of seed coating with polymer, fungicide and insecticide on Field emergence (\%) of sorghum seeds during storage (2009-10)

\begin{tabular}{|c|c|c|c|c|c|c|c|c|c|c|c|c|c|}
\hline \multirow[t]{2}{*}{ Treatment $(T)$} & \multicolumn{12}{|c|}{ Duration (Months after storage) } & \multirow{3}{*}{ Mean } \\
\hline & \multicolumn{2}{|c|}{ Initial } & \multicolumn{2}{|c|}{2} & \multicolumn{2}{|c|}{4} & \multicolumn{2}{|c|}{6} & \multicolumn{2}{|c|}{8} & \multicolumn{2}{|c|}{10} & \\
\hline Container (C) & $\mathrm{C}_{1}$ & $\mathrm{C}_{2}$ & $\mathrm{C}_{1}$ & $\mathrm{C}_{2}$ & $\mathrm{C}_{1}$ & $\mathrm{C}_{2}$ & $\mathrm{C}_{1}$ & $\mathrm{C}_{2}$ & $\mathrm{C}_{1}$ & $\mathrm{C}_{2}$ & $\mathrm{C}_{1}$ & $\mathrm{C}_{2}$ & \\
\hline $\mathrm{T}_{0}$ & 76 & 82 & 73 & 76 & 70 & 74 & 66 & 70 & 62 & 67 & 54 & 61 & 69 \\
\hline $\mathrm{T}_{1}$ & 83 & 85 & 78 & 75 & 77 & 78 & 73 & 75 & 67 & 70 & 62 & 68 & 74 \\
\hline $\mathrm{T}_{2}$ & 85 & 84 & 71 & 69 & 72 & 72 & 70 & 72 & 60 & 70 & 63 & 65 & 71 \\
\hline$T_{3}$ & 84 & 85 & 80 & 80 & 76 & 79 & 73 & 75 & 69 & 70 & 63 & 68 & 75 \\
\hline $\mathrm{T}_{4}$ & 86 & 86 & 84 & 87 & 80 & 84 & 75 & 80 & 70 & 75 & 68 & 72 & 79 \\
\hline$T_{5}$ & 83 & 86 & 80 & 80 & 75 & 76 & 70 & 72 & 65 & 69 & 66 & 65 & 74 \\
\hline \multirow[t]{2}{*}{ Mean } & 82 & 85 & 78 & 78 & 75 & 77 & 71 & 74 & 65 & 70 & 63 & 66 & \\
\hline & C & & $\mathrm{T}$ & & D & & $\mathrm{C} \times \mathrm{T}$ & & $C \times D$ & & $T \times D$ & & $C \times T \times D$ \\
\hline $\mathrm{CD}(p=0.05)$ & 0.43 & & 0.74 & & 0.74 & & 1.05 & & 1.05 & & 1.81 & & 2.57 \\
\hline
\end{tabular}

Table 6: Influence of seed coating with polymer, fungicide and insecticide on Field emergence (\%) of sorghum seeds during storage (2010-11)

\begin{tabular}{|c|c|c|c|c|c|c|c|c|c|c|c|c|c|}
\hline \multirow{3}{*}{$\begin{array}{l}\text { Treatment }(\mathrm{T}) \\
\text { Container }(\mathrm{C}) \\
\end{array}$} & \multicolumn{12}{|c|}{ Duration (Months after storage) } & \multirow{3}{*}{ Mean } \\
\hline & \multicolumn{2}{|c|}{ Initial } & \multicolumn{2}{|c|}{2} & \multicolumn{2}{|c|}{4} & \multicolumn{2}{|c|}{6} & \multicolumn{2}{|c|}{8} & \multicolumn{2}{|c|}{10} & \\
\hline & $\mathrm{C}_{1}$ & $\mathrm{C}_{2}$ & $\mathrm{C}_{1}$ & $\mathrm{C}_{2}$ & $\mathrm{C}_{1}$ & $\mathrm{C}_{2}$ & $\mathrm{C}_{1}$ & $\mathrm{C}_{2}$ & $\mathrm{C}_{1}$ & $\mathrm{C}_{2}$ & $\mathrm{C}_{1}$ & $\mathrm{C}_{2}$ & \\
\hline$T_{0}$ & 76 & 82 & 73 & 76 & 70 & 74 & 66 & 70 & 62 & 67 & 54 & 61 & 69 \\
\hline $\mathrm{T}_{1}$ & 83 & 85 & 75 & 79 & 72 & 79 & 71 & 75 & 65 & 70 & 59 & 65 & 73 \\
\hline $\mathrm{T}_{2}$ & 83 & 84 & 78 & 77 & 67 & 80 & 73 & 87 & 69 & 78 & 63 & 73 & 76 \\
\hline $\mathrm{T}_{3}$ & 84 & 85 & 72 & 84 & 68 & 73 & 72 & 79 & 69 & 70 & 65 & 69 & 74 \\
\hline $\mathrm{T}_{4}$ & 86 & 87 & 85 & 87 & 82 & 89 & 80 & 84 & 75 & 79 & 70 & 73 & 81 \\
\hline$T_{5}$ & 82 & 88 & 76 & 78 & 73 & 74 & 70 & 72 & 68 & 71 & 62 & 69 & 74 \\
\hline \multirow[t]{2}{*}{ Mean } & 82 & 85 & 76 & 80 & 72 & 78 & 72 & 78 & 68 & 72 & 62 & 68 & \\
\hline & C & & $\mathrm{T}$ & & D & & $\mathrm{C} \times \mathrm{T}$ & & $C \times D$ & & $T \times D$ & & $C \times T \times D$ \\
\hline $\mathrm{CD}(p=0.05)$ & 0.36 & & 0.62 & & 0.62 & & 0.88 & & 0.88 & & 1.52 & & 2.15 \\
\hline
\end{tabular}


Long Giang and Rame Gowda (2007) in hybrid rice. Higher field emergence recorded in chemical treated seeds might be due to the protection of seeds by the chemicals and polymers against storage insects and moulds development, which intern help in better establishment of seedling.

\section{Conclusion}

Identify the suitable polymer combination treatment that could reduce the deterioration and improve the seed viability during storage. From the observations it is inferred that the seeds coated with different combinations of polymer with insecticides and fungicides deteriorate at slower pace as manifested with higher percentage germination and vigour with less seed infection over the control.

\section{References}

Almeida, A.D.S., Deuner C., Borges, C.T., Jauer, A., Meneghello, G.E., Tunes, L.M., Villela, F. A., Zimmer, P. D., 2014. Physiological performance of rice seed treated to thiamethoxam and placed under storage. American Journal of Plant Science 5, 3788.

Gevrek, M., Gulden, A.D., Ali, Y., 2012. Growth and yield response of rice (Oryza sativa L.) to different seed coating agents. International Journal of Agriculture and Biology 14(5), 826-830.

Gomathi, G., Malarkodi, K., Ananthi M., 2014. Pre sowing seed management techniques on initial seed quality parameters in blackgram Cv. ADT-3. International Journal of Scientific Research 3(1), 13-14.

Kaushik, S.K., Rai, A.K., Singh, V., 2014. Seed quality of maize with polymer film coating in storage. International Journal of Innovative Research Science, Engineering and Technology 3(7), 14353-14358.

Kumar, J., Nisar, K., Arun Kumar, M.B., Walia, S., Shakil, N.A., Prasad, R., Parmer, B.S., 2007. Development of polymeric seed coats for seed quality enhancement of Soyabean (Glycine max). Indian Journal of Agricultural Sciences 77(11), 738-43.

Kunkur, V., Hunje, R.N.K., Patil, B., Vyakaranahal, B.S., 2007. Effect of seed coating with polymer, fungicide and insecticide e on seed quality in cotton during storage. Karnataka Journal of Agricultural Sciences 20(1), 137-139.

Maiti, R., Pramanik, K., 2013. Vegetable seed priming: a low cost, simple and powerful technique for farmers' livelihood. International Journal of Bio-resource and Stress Management 40(4), 475-481.

$\mathrm{Ni}$, B.R., 1997. See coating, film coating and pelleting. In: Seed Industry and Agricultural Development. Chinese Association of Agricultural Sciences. DOA, Ministry of Agriculture, Beijing, China Agriculture press 737-747.
Panse, V.G., Sukhatme, P.V., 1985. Statistical Methods for Agricultural Workers. ICAR Publication, New Delhi, 327-340.

Giang, P.L., Gowda, R., 2007. Influence of seed coating with synthetic polymers and chemicals on seed quality and storability of hybrid rice (Oryza sativa L.). Omonrice 15, 68-74.

Pradhan, S., 1964. Assessment of losses caused by insect pests of crops and estimation of insect population. Entomology in India (Silver Jubilee Number) 17, 50.

Rettinassababady, C., Ramanadane, T., Renuka, R., 2012. Role of polymer coating on seed quality status of hybrid rice (Oryza sativa L.) during storage under coastal ecosystem. Journal of Biological and Chemical Research 29(2), 142-150.

Robbani, H., 1994. Film coating horticultural seed. Horticultural Technology 4, 104-105.

Savitri, H., Sugunakar Reddy, M., Murali Mohan Reddy, B., 1994. Effect of seed treatment with fungicides and insecticides on seed-borne fungi, storage insect pests, seed with fungicides and insecticides on seed borne fungi, storage insect pests, seed viability and seedling vigour in sorghum. Seed Research 22(2),146-155.

Shakuntala, N.M., Vyakaranahal, B.S., Shakargowda, I., Deshpande, V.K., Pujari, B.T., Nadaf, H.L., 2010. Effect of seed polymer coating on growth and yield of sunflower hybrid RSFH-130. Karnataka Journal of Agricultural Sciences 23(5), 708-711.

Tiwari, D.K., Pandey, P., Giri, S.P., Dwivedi, L., 2011. Effect of gibberellic acid $\left(\mathrm{GA}_{3}\right)$ and other plant growth regulators on hybrid rice seed production. Asian Journal of Plant Science 10, 133-139.

Vanangamudi, K., Srimathi, P., Natarajan, N., Bhaskaran, M., 2003. Current scenario of seed coating polymer. In: proceedings of ICAR-short course on seed hardening and pelleting technologies for rainfed garden land ecosystems, New Delhi, 80-100.

Veraja, P., Rai, P.K., 2015. Effect of polymer coating chemicals and biocontrol agents on storability of blackgram (Vigna mungo L.). International Journal of plant and soil science 8(6), 1-8.

Verma, O., Verma, R.S., 2014. Effect of seed coating material and storage containers on germination and seedling vigour of soybean (Glycine max L.). SAARC Journal of Agriculture 5, 3788.

Zeng, D., Shi, Y., 2008. Preparation and application of a novel environmentally friendly organic seed coating for rice. American-Eurasian Journal of Agronomy 1, 19-25. 